SJ Quinney College of Law, University of Utah Utah Law Digital Commons

Negative Freedom in Crisis Times

Leslie Francis

Follow this and additional works at: https://dc.law.utah.edu/scholarship

Part of the Constitutional Law Commons, Health Law and Policy Commons, Law and Society Commons, and the Social Welfare Law Commons 


\section{Negative Freedom in Crisis Times}

The United States is famously regarded as a bastion of negative liberty. Its constitutional guarantees in the Bill of Rights are primarily a list of protections from the government. Internationally, the United States has steadfastly refused to ratify any of the human rights instruments that guarantee social rights: the Convention on the Elimination of All Forms of Discrimination against Women, the Convention on the Rights of the Child, and the Convention on the Rights of Persons with Disabilities, among others. Domestically, the United States remains an outlier among developed countries in its failure to provide legal rights to paid family leave or universal health care. Both the lack of access to health care and the economic need to work despite illness are structural features of U.S. society that have been judged major contributors to the devastating impact of the pandemic emergency in that society.

The United States' commitment to negative liberty is compounded, moreover, by how that liberty has been understood, especially with respect to the person. A classic distinction between liberty and license is found throughout liberal theory. ${ }^{1}$ The former may have boundaries in the choices that are included; rights to liberty do not include choices beyond those boundaries. Rights to liberty are not overridden in areas beyond the boundaries; rather, they simply do not exist. The latter celebrates the individual's right to do whatever he or she wishes with respect to her person. Such rights to license must then be overridden when they risk harm to others. In the U.S. today, negative rights to freedom of the person are being construed not as bounded liberty, but as unlimited rights to choose with respect to the person. Thus understood as license, negative rights to personal liberty come inevitably into conflict with public health measures such as vaccination or even requirements to wear masks. This conflict has come into sharp relief during the current pandemic emergency, straining trust in government and in public health.

The distinction between negative liberty - freedoms from - and positive liberty - freedoms tois of course suspect. ${ }^{2}$ Every freedom from requires some protections; freedom from government interference with speech requires protections from that interference. Moreover, some U.S. constitutional guarantees involve rights to resources: rights to a trial by jury and rights to legal counsel in criminal cases where the sentence might be imprisonment are two of the best-known examples. Even granting the problematic nature of the negative/positive division, however, the U.S. remains an outlier in the emphasis it gives to protecting individuals from interferences with their choices while concomitantly failing to provide them with resources to deal with the impacts of these choices by themselves and others. In what follows, I will set aside these problems with the distinction between negative and positive liberty and focus instead on challenges to negative liberty as license presented by the pandemic emergency.

\footnotetext{
${ }^{1}$ E.g., John Locke, Second Treatise of Civil Government, Ch. II, ed. Peter Laslett. London: Cambridge University Press 1967.

${ }^{2}$ The classic statement of this critique is MacCallum, G. C. Jr., 1967, 'Negative and Positive Freedom', Philosophical Review, 76: 312-34; see generally, Carter, Ian, "Positive and Negative Liberty", The Stanford Encyclopedia of Philosophy (Winter 2019 Edition), Edward N. Zalta (ed.), URL = <https://plato.stanford.edu/archives/win2019/entries/liberty-positive-negative/>.
} 
The COVID-19 pandemic is widely judged by commentators to have revealed deep fissures in the U.S. social fabric, especially in access to health care. ${ }^{3}$ Equally evident are the fissures it has revealed in U.S. views about freedom. Some have asserted constitutional rights to be free from even simple public health measures, such as requirements to wear masks or to forego singing in public. Others have objected to measures restricting large gatherings as violations of the free exercise of religion, and the U.S. Supreme Court has agreed with at least some of these objections. The irony of these claims to negative liberty, however, is that they may directly impede the liberties of others to be free from threats to their physical well-being. Freedom from wearing a mask is not like freedom from gunshots or speech suppression. When someone is free from wearing a mask, she may present a risk to others in her vicinity if she exercises that freedom. When someone is free from a gunshot, by contrast, she presents no risks to others whatsoever in virtue of that freedom.

In what follows, I explain how a public health crisis reveals a deep crisis in negative liberty as it is understood in the U.S. today as license rather than as bounded liberty. My first example is requirements to wear masks, where the public health benefits are clear but the law remains at best not fully resolved in support of the permissibility of these requirements. My second example is the free exercise of religion, which the U.S. Supreme Court robustly protected over public health concerns in November. At the center of this jurisprudence is contemporary interpretation of a case decided by the U.S. Supreme Court over 100 years ago, Jacobson $v$. Massachusetts. ${ }^{4}$ I begin with a brief account of the decision and its subsequent history, which features a shift in conceptualization from bounded liberty to license.

\section{Jacobson, Liberty, and Public Health Powers}

In 1902, the city of Cambridge, Massachusetts, was experiencing a smallpox outbreak. Massachusetts law permitted city boards of health to require free vaccination of all adults and to impose a $\$ 5$ fine on those who refused vaccination. Jacobson refused vaccination without claiming exemption for health reasons. Instead, he claimed that the requirement violated his rights under the letter and the spirit of the $14^{\text {th }}$ Amendment provision that "no state may enforce any law abridging the privileges or immunities of citizens of the United States, nor deprive any person of life, liberty, or property without due process of law." 5

In deciding the case, the Supreme Court refused to discuss Jacobson's claim that the Massachusetts ordinance violated the "spirit" of the Constitution, on the basis that the Constitution's words spoke plainly enough. ${ }^{6}$ The state's "police power" to enact quarantine and other health laws within its territory encompasses "such reasonable regulations established directly by legislative enactment as will protect the public health and the public safety."7 Against this authority, Jacobson argued that "a compulsory vaccination law is unreasonable, arbitrary, and oppressive, and, therefore, hostile to the inherent right of every freeman to care for

\footnotetext{
${ }^{3}$ E.g., Nancy Krieger. 2020. ENOUGH: COVID-19, Structural Racism, Police Brutality, Plutocracy, Climate Change - and Time for Health Justice, Democratic Governance, and an Equitable, Sustainable Future, American Journal of Public Health 110(11): 1620-1623.

${ }^{4}$ Jacobson v. Massachusetts, 197 U.S. 11 (1905).

5197 U.S. at 14.

6197 U.S. at 22.

7197 U.S. at 25.
} 
his own body and health in such way as to him seems best..."8 To this contention, the Court replied that

the liberty secured by the Constitution of the United States to every person within its jurisdiction does not import an absolute right in each person to be, at all times and in all circumstances, wholly freed from restraint. There are manifold restraints to which every person is necessarily subject for the common good. On any other basis organized society could not exist with safety to its members. Society based on the rule that each one is a law unto himself would soon be confronted with disorder and anarchy. Real liberty for all could not exist under the operation of a principle which recognizes the right of each individual person to use his own, whether in respect of his person or his property, regardless of the injury that may be done to others. . Even liberty itself, the greatest of all rights, is not unrestricted license to act according to one's own will. It is only freedom from restrain under conditions essential to the equal enjoyment of the same right by others. ${ }^{9}$

In this passage, the Court criticizes Jacobson's assertion of liberty as the freedom to do with his person or his possession as he sees fit. Instead, the Court says, liberty is not "license" but exists within conditions of the equal enjoyment of the same liberties by others. On this view, the enjoyment of liberties associated with health and security by one must be consistent with the enjoyment of liberties associated with health and security by others. Importantly, this picture is not one of conflicting liberties, raising questions about which liberty prevails in cases on conflict. Rather, the envisioned limits are internal to the liberties themselves; there are no liberties to do whatever one sees fit without regard to the health and security of others. There are only liberties to do what one wishes with one's own health to the extent that others enjoy similar liberties.

With this understanding of liberty, the Jacobson Court then assesses the vaccination mandate. As a first step, the legislature has the authority to decide when vaccination is necessary for the public safety, an authority that courts may not second-guess ${ }^{10}$ so long as the decision has "a real or substantial relation to the protection of the public health and the public safety." Jacobson's claims that vaccines often cause injury and occasionally cause death, that vaccination materials may be impure or unsafe, or that it is impossible to tell who may be at risk from vaccination are treated as efforts to impose minority will on legislative judgment and as stripping the legislature of its functions in protecting the public. That is, Jacobson's views about vaccination are lined up as in conflict with the legislature's judgments about vaccination. Importantly, the claims are not treated as a conflict between Jacobson's liberty rights and the public health, as the Court has already determined that Jacobson's rights to health are delineated by the similar rights of others to health.

\footnotetext{
8197 U.S. at 26

9197 U.S. at 26-27.

${ }^{10} 197$ U.S. at 27.

11197 U.S. at 31.
} 
Then, "[b]efore closing," the Court notes that there may be cases in which the legislature imposes "regulations so arbitrary and oppressive ... as to justify the interference of the courts to prevent wrong and oppression..."12 That is, there may be cases in which the state intrudes into the individual's liberty as properly understood. In Jacobson, there was no showing of such intrusion. Jacobson had not contended that he was at any risk from vaccination. However, in an "extreme case," in which a person would be subject to vaccination in a condition in which it would be "cruel and inhuman in the last degree," courts should presume that the legislature "intended exceptions to its language which would avoid results of this character." 13 In the language of many court decisions of a century ago, the "reason of the law in such cases should prevail over its letter." ${ }^{14}$ In this closing note, the Court does not assume a general conflict between individual liberties and the public health. Rather, it envisions the possibility that legislatures might adopt requirements that overreach into protected liberty because of how they threaten the life or health of individuals. In such cases, legislative actions must be construed to avoid these threats.

Many later courts have not construed Jacobson by emphasizing its distinction between liberty and license, as just described. Instead, a standard reading is that Jacobson imposes a two-part test on public health requirements: does the legislative action have a real or substantial relationship to protecting the public health, and does it do so without being a plain, palpable invasion of individual rights? ${ }^{15}$ This construal of the Jacobson test differs from the one presented here, as it balances the substantiality of the state's interest against the extent of intrusion on individual rights. That is, it construes individual rights and the public health as in potential conflict, without beginning with the assumption of the Jacobson Court that individual rights are themselves limited by the equal rights of others. In the discussion to follow about masks and the free exercise of religion, I consider the problematic influence of this view of Jacobson as enshrining a strong version of negative liberty rights.

\section{Masks}

Masks are widely recommended as one among many important measures to prevent the spread of COVID-19 infections. ${ }^{16}$ Evidence is overwhelming that, when properly worn, masks reduce the likelihood that people will transmit infection, will become infected, or perhaps even contract more serious disease if they do become ill. In the early days of the pandemic, however, messages in the U.S. about the importance of masks were at best mixed. In part because of concerns that N-95 masks needed by health care workers would be in short supply, and in part because SARS-CoV-2 was such an unknown infectious agent, public health authorities initially

\footnotetext{
12197 U.S. at 38.

13197 U.S. at 39.

${ }^{14} 197$ U.S. at 39 (quoting United States v. Kirby, 7 Wall. 482; Lau Ow Bew v. United States, 144 U.S. 47, 58)).

${ }^{15}$ E.g. Lawrence O. Gostin. 2005. Jacobson v. Massachusetts at 100 Years: Police Power and Civil Liberties in Tension. American Journal of Public Health 95(4): 576-581.

${ }^{16}$ E.g., Lynne Peeples. 2020. Face masks: what the data say, Nature 586: 186-189. https://doi.org/10.1038/d41586$\underline{020-02801-8}$.
} 
downplayed or outright disparaged the efficacy of masks. ${ }^{17}$ U.S. President Trump mocked maskwearers and repeatedly hosted events at which people were not required to wear masks. ${ }^{18}$ Support for masking became highly politicized, with data indicating that people identifying as Republicans far more likely to object to masks than people identifying as Democrats. ${ }^{19}$ Mask opponents claimed that masking requirements violated their constitutional rights. ${ }^{20}$

Following public health guidelines, many jurisdictions in the U.S. have issued mask mandates for circumstances in which social distancing cannot be maintained. These mandates typically have exceptions, such as for people for whom they would pose a health risk or for people who require lipreading to communicate. Many of these mandates were issued by governors or mayors under public health emergency powers. In some jurisdictions, the use of emergency powers by the executive branch for extended periods of time was an additional source of controversy. State legislators objected to what they viewed as overreach by the executive into areas that should be the subject of legislative oversight and introduced legislation to curtail executive emergency powers. ${ }^{21}$ In what follows, I lay these important procedural questions aside, focusing instead on the substantive questions about constitutional liberty raised by mask mandates.

Constitutional challenges to mask mandates have reached a significant number of courts. Constitutional claims raised by mask opponents prominently include freedom of expression, on the basis that being required to wear a mask is a form of compelled symbolic speech. Another free speech claim is that masks suppress speech in the form of visible facial expressions. Also cited in opposition to the mandates are rights to personal autonomy, bodily integrity, privacy, and rights to refuse medical interventions. The privacy claim is that an individual with a legitimate medical exemption to wearing a mask would be forced to disclose physical or mental health conditions in order to substantiate their claims to exemption. ${ }^{22}$ These claims conceptualize mask requirements as interferences with individuals who would prefer not to wear masks, rather than as protection of others from dangerous conduct on the part of opponents of masking. U.S. court decisions have largely left this conceptualization unchallenged.

Some lawsuits challenging mask mandates have been dismissed for lack of standing. These cases determine that opponents of masking lack sufficiently individualized claims of harm to bring to

${ }^{17}$ E.g., Megan Molteni \& Adam Rogers. 2020 How Masks Went From Don't-Wear to Must-Have. WIRED [online] (July 2). https://www.wired.com/story/how-masks-went-from-dont-wear-to-must-have/ . Last visited Dec. 14, 2020.

${ }^{18}$ Robin Givhan. 2020. Trump's refusal to wear face masks turned them into a sad national symbol. The Washington Post [online] (Oct. 3). https://www.washingtonpost.com/nation/2020/10/03/trumps-refusal-wear-face-masks-turnedthem-into-sad-national-symbol/ . Last visited Dec. 14, 2020.

${ }^{19}$ Patrick van Kessell \& Dennis Quinn. 2020. Both Republicans and Democrats cite masks as a negative effect of COVID-19, but for very different reasons. Pew Research FACTTANK (Oct. 29). https://www.pewresearch.org/facttank/2020/10/29/both-republicans-and-democrats-cite-masks-as-a-negative-effect-of-covid-19-but-for-verydifferent-reasons/. Last visited Dec. 14, 2020.

${ }^{20}$ Helena Rosenblatt. 2020. No, there isn't a constitutional right to not wear masks. The Washington Post [online] (Aug. 20). https://www.washingtonpost.com/outlook/2020/08/20/no-there-isnt-constitutional-right-not-wear-masks/. Last visited Dec. 14, 2020.

${ }^{21}$ National Conference of State Legislatures. 2020. Legislative Oversight of Emergency Executive Powers (Dec. 7). https://www.ncsl.org/research/about-state-legislatures/legislative-oversight-of-executive-orders.aspx . Last visited Dec. 14, 2020.

${ }^{22}$ E.g., Shelton v. City of Springfield, Missouri, -- F.Supp.3d --, 2020 WL 6323935 (Oct. 28, 2020) at*2. 
court. Dismissals on standing thus have given no substantive guidance regarding the constitutionality of mask orders. An illustrative case of this type is Parker $v$. Wolf, ${ }^{23}$ decided in December 2020 by the Pennsylvania federal district court. The plaintiffs sought a preliminary injunction against the mandate imposed by the state's governor, claiming that they were harmed by its imposition. The court rejected their suit on the theory that they lacked standing, first, because they did not suffer a sufficiently individualized harm. Instead, the court said, they were asserting a "generalized grievance" of the kind that might be claimed by any member of the public. A second reason advanced by the court for rejecting the plaintiffs' suit was that the remedy they sought, injunctive relief, would not redress their alleged harm. Here, the problem was that although they challenged the governor's order, many local areas and businesses would still require masks even if the governor's order were suspended. Finally, the plaintiffs had not shown that they faced the likelihood of enforcement actions if they were to appear in public without masks. In a decision relied on by the Parker court, the federal district court in Missouri had determined that a plaintiff who feared she would be forced to disclose her mental health condition in order to justify her medical exemption from the mask requirement did not face danger of immediate injury because she had not shown actual enforcement of the mandate against her. ${ }^{24}$

In other cases, plaintiffs' standing has not been challenged. For example, in Stewart v. Justice, restaurant owners challenged the order of the West Virginia governor compelling businesses to require masks and to post signs to that effect. ${ }^{25}$ The West Virginia federal district court applied the standard interpretation of Jacobson described above as problematic. Jacobson, the district court said, "teaches that . . the standard of review is highly deferential" in challenging public health orders. ${ }^{26}$ Quoting Jacobson, the district court said that a successful challenge to a public health order must show either that the order "has 'no real or substantial relation' to protecting public health" or that "it is "beyond all question, a plain, palpable invasion of rights secured by the fundamental law." 27 On the first point, the district court concluded that the Stewart plaintiffs had failed to show that the mask mandate lacked a rational basis. On the second point, the application of Jacobson to fundamental First Amendment rights, the district court also found Jacobson "instructive" in stating that " all constitutional rights may be reasonably restricted to combat a public health emergency." 28 In other words, the Stewart court weighed what it supposed to be constitutionally protected rights against public health and found that public health prevailed.

This view of public health powers has since been rejected by the Supreme Court for the free exercise of religion, as discussed in the next section of this essay. Worth explicating here is that

\footnotetext{
23 -- F.Supp.3d --, 2020 WL 7295831 (M.D. Pa. 2020). Similar rulings that plaintiffs lack standing to challenge mask mandates are Young v. Becksted, 2020 WL 7029509 (D.N.H. Nov. 10, 2020); Young v. Frosh, 2020 WL 6585958 (D. Md. Nov. 10, 2020); Shelton v. City of Springfield, 2020 WL 6323935 (W.D. Mo. Oct. 28, 2020); Cangelosi v. Edwards, 2020 WL 6449111(E.D. La. Nov. 3, 2020); Bechade v. Baker, 2020 WL 56665554 (D. Mass. Sept. 23, 2020).

${ }^{24}$ Shelton v. City of Springfield, Missouri, -- F.Supp.3d --, 2020 WL 6323935 (Oct. 28, 2020).

25 Andrew Stewart, Ashley Stewart, Dinner's Ready, Inc. v. James L. Justice III, 2020 WL 6937725 (S.D. W. Va. Nov. 24, 2020).

${ }^{26}$ Stewart, 2020 WL 6937725 at $* 2$.

27 Stewart, 2020 WL 6937725 at $* 2$.

${ }^{28}$ Stewart, 2020 WL 6937725 at $* 5$ (quoting in re Abbott, 954 F.3d 772, 786 (5 $5^{\text {th }}$ Cir. 2020)) (italics in original).
} 
the problem posed by the Stewart plaintiffs' free speech claims may not be analogous to the free exercise claims sustained by the Court against mandates closing churches. The Stewart plaintiffs argued that the requirement to wear a mask compelled symbolic expression of political views about the corona virus. The mandate, in their view, was thus a content-based restriction on speech that could only be sustained on a showing that it met the constitutional test of strict scrutiny. That test requires a compelling state interest and a regulation narrowly tailored to serve that interest. To reject the Stewart plaintiffs' argument, the district court found that mask wearing did not possess "sufficient communicative elements to bring the First Amendment into play..." 29 People might not wear masks for many reasons, including carelessness, the district court said, so a wearer's political views could not be inferred from the presence of a facial covering. Moreover, even if masks implicated speech, the district court said, a requirement to wear them was at best a restriction on the time, place, or manner of speech, not its content. The level of scrutiny to be applied for time, place, and manner restrictions is the intermediate requirement of narrow tailoring to a significant government interest, leaving open ample alternative channels for communicating the ideas in question. This level, the district court concluded, could easily be met by a mask mandate.

Other decisions upholding mask mandates have similarly applied Jacobson to respect sweeping public health powers. For example, New York Governor Cuomo's emergency orders, which included guidelines permitting restaurants to open with indoor dining only with mask-wearing and social distancing, were upheld under the state's "especially broad authority" when acting under conditions of uncertainty in the face of a serious public health threat. ${ }^{30}$

On the other side, in some cases proponents of mask wearing have failed in efforts to challenge state decisions not to require masking, apparently relying on without directly addressing conceptualization of liberty rights to the person as license. This has occurred even when the right to vote was threatened by the absence of masks. In Mi Familia Vota v. Abbott, the plaintiffs challenged an exemption in the governor's mask mandate for persons who are voting, assisting voters, serving as poll watchers, or actively administering an election. ${ }^{31}$ The plaintiffs were Black and Hispanic voters who claimed that the exemption violated the federal Voting Rights Act by disproportionately affecting their right to vote. ${ }^{32}$ The situation in Texas for Hispanic voters was particularly dire; as of early December 2020, 53\% of the COVID-19 deaths in Texas were among Hispanics, who made up only $40 \%$ of the population overall. ${ }^{33}$ In reversing a district court grant of a preliminary injunction against the exception, the Fifth Circuit Court of Appeals examined only whether the federal courts would be improperly altering election rules in the midst of the election. Governor Abbott had introduced evidence from several local election officials that the requirement

\footnotetext{
${ }^{29}$ Stewart, 2020 WL 6937725 at *5 (quoting Texas v. Johnson, 491 U.S. 397,404 (1989)).

${ }^{30}$ Bimber's Delwood, Inc. v. James, 2020 WL 6158612 (W.D. N.Y. Oct. 21, 2020) at*6.

${ }^{31}$ Mi Familia Vota v. Abbott, -- Fed. Appx. -- , 2020 WL 6498958 (5 ${ }^{\text {th }}$ Cir. Oct. 30, 2020).

3252 U.S.C. $\S 10301$ (a) (no . . standard, practice, or procedure shall be imposed or applied by any State or political subdivision in a manner which results in denial or abridgement of the right of any citizen of the United States to vote on account of race or color..."

${ }^{33}$ The situation for Blacks was more favorable; Blacks are $12 \%$ of the Texas population but $10 \%$ of the deaths, while whites are $41 \%$ of the population but only $34 \%$ of the deaths. Kaiser Family Foundation. 2020. State Health Facts: COVID-19 Deaths by Race/Ethnicity (Dec. 6). https://www.kff.org/other/state-indicator/covid-19-deaths-byraceethnicity/?currentTimeframe=0\&sortModel=\%7B \%22colId\%22:\%22Location $\% 22, \% 22$ sort $\% 22: \% 22 \mathrm{asc} \% 22 \% 7 \mathrm{D}$. Last visited Dec. 14, 2020.
} 
to wear masks would be confusing to voters. ${ }^{34}$ The injunction, issued one week before election day, would clearly alter Texas's election rules during the election. Thus, the Fifth Circuit concluded, the invalidation of the mask exception would cause the state irreparable injury. Nowhere did the Fifth Circuit even consider the plaintiffs' claims that their rights to vote were disparately affected by the likelihood they would encounter voters, poll workers, and poll watchers without masks.

None of these decisions address whether the liberty not to wear a mask is properly viewed as a negative liberty to be free of any interference on the part of individuals to do what they wish with regard to their bodies. Instead, even when they uphold mask mandates, the decisions view the choice as between individual liberty and general protection of the public health. No reported decisions ${ }^{35}$ apparently ask whether the liberty claimed is more like a liberty to risk harms to others than like a liberty to be free from state interference with otherwise innocuous behavior. This failure is especially troubling in light of the U.S. Supreme Court's decision casting significant doubt on the viability of reading Jacobson to support generous public health powers, to which I now turn.

\section{Public Health and the Free Exercise of Religion}

In the face of sharply rising COVID-19 caseloads and fears that hospitals would be overwhelmed, U.S. states have imposed, relaxed, and re-imposed various closure orders. Among the most controversial have been orders limiting in-person religious services. In November 2020, the U.S. Supreme Court struck down one such order issued by Governor Cuomo of New York. ${ }^{36}$ The order imposed 10-person limits on attendance at religious services in "red" areas and 25-person limits in "orange" areas. The Roman Catholic Diocese of Brooklyn and Agudath Israel of America challenge these restrictions as violating the First Amendment right to the free exercise of religion and sought injunctive relief. In a per curiam opinion, marked by concurrences and dissents, the Court granted the relief sought. The standard applied for the grant of injunctive relief was that the First Amendment claims are likely to prevail, that denial of the relief would lead to irreparable injury, and that granting relief would not harm the public interest. ${ }^{37}$

To analyze the likelihood of success on the merits, the Court began by characterizing the order as violating minimum requirements of religious neutrality "because they single out houses of worship for especially harsh treatment." 38 In comparison to religious facilities, businesses characterized as essential were not subject to these limits in red zones, including campgrounds, garages, and transportation facilities. In orange zones, moreover, non-essential businesses were allowed to decide for themselves on how many persons to admit. As non-neutral, then, the order would be required to pass the difficult test of strict scrutiny: being narrowly tailored to serve a compelling state interest. Here, the problem was not the compelling interest of protecting public health, but the tailoring of the order. The government had not shown that either the Diocese or Agudath Israel had been the source of COVID-19 outbreaks or had failed to implement safety protocols.

\footnotetext{
${ }^{34}$ Mi Familia Vota, 2020 WL 6498958 at *3.

${ }^{35}$ My search strategy in Westlaw of "covid \& mask \& mandate" yielded 280 cases decided by the U.S. federal courts as of December 13, 2020.

${ }^{36}$ Roman Catholic Diocese of Brooklyn v. Cuomo, -- S.Ct. -- , 2020 WL 6948354 (Nov. 25, 2020).

${ }^{37}$ Roman Catholic Diocese, 2020 WL 6948354 at $* 1$.

${ }^{38}$ Roman Catholic Diocese, 2020 WL 6948354 at $* 1$.
} 
Moreover, less restrictive constraints might be imposed to enforce social distancing, such as tailoring numbers admitted for services to the size of the religious edifice. All of the Court's criticism addressed the scope of the public health concerns. Nowhere in the opinion does the Court interrogate the boundaries of the free exercise of religion.

Nor did the concurrences raise significant issues about the contours of the free exercise of religion. Justice Gorsuch excoriated the lines drawn by the Governor's order: “...it turns out the businesses the Governor considers essential include hardware stores, acupuncturists, and liquor stores. Bicycle repair shops, certain signage companies, accountants, lawyers, and insurance agents are all essential too. So, at least according to the Governor, it may be unsafe to go to church, but it is always fine to pick up another bottle of wine, shop for a new bike, or spend the afternoon exploring your distal points and meridians. Who knew public health would so perfectly align with secular convenience?"39 Those concerned with socially distanced transit or pain relief might take issue with Justice Gorsuch's characterization of biking or acupuncture as "secular convenience," but leaving this point aside Justice Gorsuch simply characterized the Court's view of religious liberty as "long and settled," a "first freedom [that] has fallen on deaf ears." 40 Then, Justice Gorsuch distinguished Jacobson as applying limited rational basis scrutiny to a public health order, a level of scrutiny appropriate when fundamental rights or suspect classifications are not involved. The limits on religion imposed by the Governor's order, Justice Gorsuch said, were different from Jacobson's claim to "'bodily integrity," a right that some judges may "have found hiding in the Constitution's penumbra" but that is quite different from "the textually explicit right to religious exercise." ${ }^{1}$ Justice Kavanaugh was more tempered, quoting Chief Justice Roberts for the tempered statement that " it may well be that such restrictions violate the Free Exercise Clause." 42

Chief Justice Roberts dissented on the basis that the need for the injunction was moot because Governor Cuomo had removed the challenged numerical restrictions in the areas affected by the religious organizations. He explicitly declined to consider whether the original capacity restrictions were unduly restrictive in support of public health. He did, however, take the occasion to object to Justice Gorsuch's biting comments about prior applications of Jacobson. Jacobson, Justice Roberts said, is not a "'towering authority that overshadows the Constitution during a pandemic," "43 but only a recognition that politically accountable offices have responsibility for the public health and safety.

Justice Breyer's dissent emphasized the findings of the district court that the New York governor's regulations were founded in science and in some respects treated religious gatherings more favorably than other gatherings with comparable risks such as concerts. He viewed with approval the district court's refusal to second guess the legislature. Because of the seriousness of the pandemic, he said, "it is far from clear" that the equities should be balanced in favor of the religious organizations and that their claim of a constitutional violation should be recognized. ${ }^{44}$ This analysis explicitly treats the problem of pandemic liberties as a conflict between the public health

\footnotetext{
${ }^{39}$ Roman Catholic Diocese, 2020 WL 6948354 at *4 (Gorsuch, J., concurring).

${ }^{40}$ Roman Catholic Diocese, 2020 WL 6948354 at*5 (Gorsuch, J., concurring).

${ }^{41}$ Roman Catholic Diocese, 2020 WL 6948354 at*5 (Gorsuch, J., concurring).

${ }^{42}$ Roman Catholic Diocese, 2020 WL 6948354 at *8 (Kavanaugh, J., concurring) (quoting Chief Justice Roberts).

${ }^{43}$ Roman Catholic Diocese, 2020 WL 6948354 at *9 (Roberts, C.J., dissenting) (quoting Justice Gorsuch).

44 Roman Catholic Diocese, 2020 WL 6948354 at *11 (Breyer, J., dissenting).
} 
and the religious rights of individuals. Justice Sotomayor, also in dissent, takes issue with the Court's argument that the New York governor's order discriminates against religious institutions, concluding that the "Constitution does not forbid States from responding to public health crises through regulations that treat religious institutions equally or more favorably than comparable secular institutions, particularly when those regulations save lives." 45 This opinion likewise leaves unquestioned the scope of religious liberties themselves.

\section{Conclusion}

Contemporary U.S. jurisprudence thus treats public health orders requiring masks or limiting attendance at religious services as conflicts between individual freedoms and the public safety. Courts have left unquestioned the scope of individual liberties. Choices about whether to cover one's face or attend religious services are not, however, fully analogous to protections from physical injury by others. Instead, they are choices that may result in risks to others. It is thus at least open to question whether they are within the scope of protected individual liberties in the first place. The scope of personal liberty - whether liberty is distinct from license - is the question at the foundation of the Jacobson decision over 100 years ago. Courts today, however, rely solely on whether the public health interest is sufficiently strong to override presumed individual liberties.

This construction of individual rights to personal liberty as license, pitted in conflict with public health, is particularly damaging in times of crisis such as the current pandemic. It encourages people to see governmental efforts to protect the public health as overweening intrusions, to be protested and defied. The pandemic emergency thus forces careful re-examination of the outer limits of personal liberty itself. Without such re-examination, the U.S. faces not only the consequences of the absence of positive liberties, but also a crisis within what has traditionally been viewed as negative liberty itself.

\footnotetext{
${ }^{45}$ Roman Catholic Diocese, 2020 WL 6948354 at *14 (Sotomayor, J., dissenting).
} 